\title{
The Development of E-Learning using Communicative Competence
}

\author{
Yuli Widiyono ${ }^{1}$, Ismawati Ike Nugraeni ${ }^{2}$, Riawan Yudi Purwoko ${ }^{3}$, Suyitno ${ }^{4}$ \\ widiyono@umpwr.ac.id ${ }^{1}$, nugraeni.ike@umpwr.ac.id ${ }^{2}$,riawanyudi.umpwr@gmail.com ${ }^{3}$, \\ yitnoback@yahoo.com ${ }^{4}$ \\ Universitas Muhammadiyah Purworejo, Purworejo, Indonesia ${ }^{1234}$
}

\begin{abstract}
The existence of Javanese language in the diversity of languages has the main point in the form of language Unggah-Ungguh. Unggah-Ungguh implies some levels of speech with different functions that can have different impacts on the personality formation, characters, and the learners' characters. The use of information and communication technology in the development of learning media is to increase the learners' interest and speaking skill of Unggah-Ungguh in classroom as well as in community. Communicative competence in the Javanese language learning helps the learners to develop communicative competence and increase awareness toward the values of local wisdom. The values of Javanese local wisdom has contributed greatly to the national cultural heritage. By inspiring and applying the values of Javanese unggah ungguh through learning media and speaking practices, it is expected to improve learners' character and support the creation of a nationality that has strong dignity with its values of language, literature, and noble of culture.
\end{abstract}

Keywords : Learning, Media, Communicative Approach, Javanese Unggah-Ungguh, Speaking Skill

\section{Introduction}

In European Charter, regional language is a traditional language used in such a territory in country by citizens who formed a numerical group. It is smaller than other populations in that country. The former director of UNESCO, Sheldon Shaeffer (2104) in an international seminar held by SEAMEO QITEP in Jakarta by the theme "The use of regional language to improve the competence of elementary school student" stated that the preservation of regional language is urgently needed. This is reinforced by the fact that 6,000 languages in the world as much as 40 percent are endangered and only 10 percent are safe. The United Nations Educational, Scientific and Cultural Organization (UNESCO) stated that 3,000 of 6,000 languages in the world are almost extinct, mostly belong to minority ethnics.

Indonesian Government through the Act of the Republic of Indonesia Number 20, 2003 on National Educational System in the article 3 seeks to stimulate thinking on how to utilize Javanese language in education to support efforts to achieve national educational goals, emphasize the development of students' comprehensive intelligence, kinesthetic, emotional, spiritual, intellectual intelligence so education can perform its the function to build dignified nation. Besides, Act Number 24 Year 2009 in the article 42 section (1) orders to develop, nurture, and protect the local languages and literature in order to preserve their positions and functions in the life of society.

Regional language, especially Javanese is used as a communication tool by the Javanese community in Java (Yogyakarta, Central Java, East Java) and outside Java, even overseas, like in Suriname [1] . Philosophically, the Javanese language has a very basic position because it does not only possess various levels such as undha usuk, but also levels of speech or Unggah-Ungguh. In addition, [2] states that Unggah-Ungguh in Javanese is the set of customs, ethics, norms, and manners. Based on this understanding, it appears that Javanese Unggah-Ungguh (the level of speech) or undha basa is not only limited to the level of politeness in speaking (Javanese variety krama and ngoko ), but it is also the concept of manners which is influential on character building.

A protected and regulated Javanese language is stipulated in the Act of the Republic of Indonesia, Government Regulations, Ministerial Regulations, Regional Regulations (Governor's Decree). This is an evidence that the Javanese language has a very strong position. However, nowdays many facts show that Javanese language has a less prominent position and function. The 
quality of the use of Javanese language has begun declining, i.e many Javanese younger generations do not master Unggah-Ungguh as well as understand Javanese culture.

Today, Javanese skills can be said as quite apprehensive. Many Javanese observers and people are worried about the existence of Javanese in the community. [3] This relates with the opinion of Javanese society in recent years, especially those in the first layer (ring one) which has the layer of society at that time directly related to the ruler (kingdom), both ruler in Yogyakarta and in Surakarta, began to worry about the existence of basic Unggah-Ungguh. The concern is due to the fact that the Javanese young generation has not begun to master Unggah-Ungguh well. As a result, there are errors in the use of Javanese language in the communication process.

Knowing the context of Javanese requires a solution to solve this serious problem. To overcome the problem, it is needed to use of information and communication technology. because the role of technology and communication is important in the development of education. The development of learning media in speaking by using them is expected to improve the learning process and foster student's interest in learning Java language. Furthermore, the framework will be offered through the use of information and communication technology in the development of learning media Unggah-ungguh in Javanese language with communicative approach. [4] defines a communicative approach as a language learning approach that emphasizes authenticity, interaction, learner-centered learning, task-based activities, and communication for real life, meaningful goals. to achieve the desired result, that is facilitate the thorough development of students' potential, character, and intellectual intelligence.

\section{Javanese Unggah-Ungguh}

[5] states that the language of a systemic nature, the arbitrary language, the language is a symbol of vocal and visual, language refers to meaning, the language used for communication tools, language as a community of speakers, the language is important for humans and may be limited to $\mathrm{p}$ there is a human, the language is used by everyone in the learning process that has the same characteristics.

Language is a communication system using sounds, spoken through the speech organs and heard among the members of society, and using the processing of vowel symbols with conventional meanings arbitrarily. Language is a set of linguistic symbol systems used in a common practice by a number that enable people to communicate and be understood from one another. Language is a system of vowel symbols that are arbitrary and used for human communication. Language is a systematic tool to convey the idea/feeling to wear signs, sound, gesture associated with the expression or signs and meaning that can be understood [5].

[6] reveals that the role or function of language is inherent in the field of study. Some experts in sociolinguistic, theories of communicative and sociocultural competence are used to regulate language communication. While in the field of pragmatic speech acts are used by speakers to perform speech acts such as asking, inform, apologize. in the field of sociology, the field of language communication is used to build social networks. [7]states that the function of language in the simplest sense, can be viewed as the equivalent of ' $p$ use '. The function of the language can be interpreted the way people use their language, or their languages if they speak more than one.

Javanese is a daily means of communication for Javanese society. In the communication process, it is important to pay attention to the rules of grammar, the opponent of speech, or whom people are invited to communicate. [8]Javanese language can be used as a vehicle for the formation of character and courtesy because it is rich and completed with vocabulary that includes: functions, rules or language norms, variations or levels of language, ethics and cultural values are high with all the roles of its function.

[8]The function of Javanese according to, among others, as follows.

1) Javanese is a cultural language in addition to communicative functioning also serves as a means of embodiment of cultural attitudes laden with noble values.

2) Javanese courtesy means knowing the boundaries of manners, knowing how to use good customs and having a sense of responsibility for the improvement of living together.

3) In order to achieve the modesty that can be a personal embellishment of a person, the conditions that must be met are as follows. 
a) Clever to reduce the feelings of others in the association,

b) Clever to respect the other person or speech partner,

c) Good at keeping the speech, not rude, and not hurt other people.

In communication using the Java language, the selection of lexicon in the process of communicating is noticed, given the rules or the level of speech language. Up bases or undha bases commonly referred to as language speech level is a wealth owned by the Java community. The uploaded bases are still applied or used by the Java community [3].

Basic Unggah-Ungguh is one of the objective features of Javanese languages that are systematically and neatly arranged as a communication tool used by the Javanese community. [9] states that the basic Unggah-Ungguh are a variation of the language whose differences are determined by the difference of polite attitudes present in the speaker to the other person. The basic Unggah-Ungguh embodies Javanese customs. Unggah-Ungguh is not limited to communication behaviors, but it is also the concept of manners to behave and be able to describe a person's personality when in a Javanese society.

Furthermore, [10] adds the term of 'courtesy' as the uniqueness of Javanese politeness. The guidelines are norms embodied in the form of idioms or phrases commonly spoken by most parents when educating their child. Some of these are in the form of positive advice by using idioms positive, and the other in the form of a ban on using forms of negative commands just 'do not' do this or that.

The Javanese people are primarily concerned with bases, Subasita, and manners. [10] states that the Javanese language uploads are customs, ethics, norms, and manners. Based on this understanding, it appears that the Javanese language-uploaded or often called the level of speech or undha basa basa not only limited to the level of politeness speak (Javanese variety krama and ngoko ), but in it there is also the concept of manners behave or behave. So in Javanese society there is proverb "Ajining dhiri saka lathi, ajining crew saka tumindak". which means people who use language and good behavior will be respected by others.

[10],[11] describe the things that must be considered in using Javanese Unggah-Ungguh in communicating with others as follows:

1) Age factor, ie, young people respect older children, and young people respect old people.

2) Kinship factor, ie young people respect the older brother, children respect the parents.

3) Factor degrees and rank, ie students respect teachers, employees honor superiors or leaders, citizens respect the head

4) The semantic factor, that is the rich person, the person who owns the vast land, the people who earn big.

5) Heredity factor, that is person who has title, bendara, raden ajeng, raden mas.

6) Factor of nobility or personal qualities, i.e people have low qualifications, heroes, humanists, artists, scholars.

7) Factor of familiarity, i.e people who do not know, people who just known, and should be more respected than people who are familiar.

In addition to the above factors, in the language, things that must be considered in determining the form of respect or ordinance to respect others there is no fixed rule. These factors are only as norms and depend on the atmosphere of (subjective) and according to the (relative) situation. Another important thing to note in the successful use of Java-base uploads is that it can avoid the use of personal krama or N1. Javanese krama is used to respect N2 and N3 with the exception of status under N1. With the development of learning model is expected to facilitate learners to know and learn and can apply Javanese Unggah-Ungguh well and correctly in order to build the learners' character.

\section{Communicative Approach in Javanese Language Learning}

[4] states "learning is a acquiring or getting of knowledge of a subject or a skill by study experience, or instruction" that learning (process) acquire or gain knowledge of the subject or a learned skill, experience, or instruction. Learning is a relatively fixed behavior change and is the 
result of repeated practice. Describes the characteristics of learning: Learning is "getting or obtaining", Learning is the retention of information or skills, Retention using saving system, memory, cognitive organization, Learning involves liveliness, focusing on consciousness and reaction to events inside and outside the organism, Learning is relatively permanent, but learners can forget, learning includes several practical types, perhaps practical reinforcement, Learning is changing behavior.

Communicative approach is an approach based on the idea that the ability to use language in communication is a goal that must be achieved in language learning. [12]states the communicative approach can be implemented in communicative language learning to ensure students successfully acquire communicative competence. He also adds that communicative learning can develop fluency and accuracy. Accuracy in the communicative approach, which can create learning activities that make students able to negotiate meaning, using communication strategies, correct errors, and strive to avoid communication bottlenecks.

[13]States that since the beginning of the twentieth century the use of neat uploads has never been done well. Until before the Second World War, Javanese from the upper classes used to switch to Malay or Dutch to avoid using their Mother tongue and to free them from modesty. In the fifties, most of them were no longer concerned about the neatness of the Javanese language.

Government policy has discussed the position of the Javanese language as a regional language since 1945. Since then, some of its functions are taken by the Indonesian language. However, because of persistence and seriousness of the Javanese characters, the position of the Javanese language is still preserved. Several factors that affect the preservation of Javanese, include: Javanese literary traditions that are already entrenched and rooted; Javanese lovers who are still quite a lot and still actively trying to keep the Java language still maintained, speakers of Java as a language that is very large number of mothers.

The development of Javanese use can be useful to instill pride, loyalty, love of the local language or mother tongue with the assumption that the community will feel possess (rumangsa handarbeni) and responsible for the preservation and development of Javanese language. In addition to requiring from the Javanese community, the development effort, and the development of Javanese language also requires institutional support related to both government and non-government institutions. The expected support from the government, especially the local government in the special region of Yogyakarta, Central Java, and East Java are the formal and strategic policies needed in the business of developing and developing the language. This is evident in the emergence of local government policy by establishing a decree on the Javanese language.

Javanese teaching for students generally aims to have communicative competence. Communicative language teaching involves the process of teaching and learning in classroom. Teaching shows and helps one to learn to do something, give instruction, guide in the study of something, give knowledge, cause to know or understand [4]. From the above description it can be concluded that the communicative approach of the Javanese language is structured on the basis of the language function and the needs of the speakers, so that it can use the language accurately and fluently in the hope that the ultimate goal can be to use language to communicate in real and purposive situations and natural communication.

\section{The Development of Learning Media in Teaching Javanese "Unggah- Ungguh" Speaking Skill}

[14] In the 21 st century the media provides a very large role, one of them as the development of critical thinking skills of learners. Nowadays, multimedia technology is growing very rapidly. This is due to the improvement of advanced and sophisticated technology. This progress has to be responded well by all including teachers. Teachers can make multimedia as one of innovative learning resources. In various studies, innovation of learning resources through multimedia can make students interested, enthusiastic, and motivated in learning which resulted in improving student achievement. [5]Technology contribution to the learning will be more transparent. In a transparent way, the role of technology in learning is on the components of computer-based evaluation so the learners can see the score directly. 
[15] defines media as a communication channel tool. The term media itself comes from the Latin. It is the plural of the word " medium " which literally means " intermediary " the intermediate source of the message (a source) with the receiver of the message (a receiver). Learning media is everything that can be used to send the message (learning materials) as well as to stimulate the attention, interest, thoughts and feelings of students in learning activities to achieve certain learning objectives. While multimedia is an amalgamation of text, color, sound, animation and video which is then presented and displayed through a computer or other digital platform. The preparation of such components requires diverse expertise from different disciplines [16].

The principle of learning media occupies a strategic position in order to create optimal learning process. The optimal learning process is one of the indicators to achieve optimal learning output. Optimal learning output is also a reflection of quality education output. Qualified education requires the resources of teachers who are able and ready to work professionally in the school and community [15].

Based on some of opinions above, it can be concluded that multimedia is a combination of visual, audio, animation integrated using computer technology that can be used with a specific purpose. by this ability, multimedia can be used for learning purposes.

Multimedia-assisted learning is essentially the use of multimedia as a tool in learning process. [17] mentions some of the benefits of computer-assisted learning as follows: Computers can increase the motivation and interactive of learners, Computers are able to provide information about errors and the amount of study time and time to work out the problems to learners, Computerassisted learning can be an alternative to overcome weaknesses in group learning, Computer-assisted learning can help students who have difficulty in learning, Reduce the sense of inferiority to students, because students are not ashamed to make mistakes and errors are not known by others. [15] states "Six forms of computer-based interaction are: drill and practice, tutorial, gaming, simulation, discovery, and problem solving". One of the software that can be used in multimedia development is Macromedia Flash. Mentions the advantages of multimedia as follows.

a. Presents visuals that show motion.

b. Can speed up or slow down a process so it is easy to understand.

c. Can learn the processes that are dangerous, expensive, complete, and rare.

d. Multimedia can be dramatized with sound and light effects.

e. The visualized material has a resemblance to the original object.

f. Can present rare events.

g. Be able to explain something difficult.

The media product is form in HD Video in Javanese. The segmentation is for senior high school. It contains communicative speech act (unggah-ungguh): daily imperative speech, request and turn-taking by paying level such as social status, age and gender.

The media is helping student to:

1. differ the using of register (ngoko and kromo) as need as Javanese rule (pakem).

2) practice and show language grammatically.

3) appreciate language and Javanese culture.

To produce a good learning media, it needs to be done by taking the correct procedures in the development process. [18] The development of learning media using appropriate steps or procedures developed outlines five stages of media development procedures that include analysis, design, development, implementation, and evaluation. Learning media in teaching Javanese Speaking Unggah-Ungguh with communicative approach prioritizes communication process between speakers with different social status, education level, and age and varied cases. Then, it will create more various communication competence. The learning media in teaching Javanese UnggahUngguh by using communicative approach is based on the concept of language as a means to express the functional meaning through language competence, discourse, sosiocultural, and actional competency. It is expected to improve language skills and communicative competence in the practice of language so that learners can communicate using Javanese properly, correctly and meaningfully. 


\section{Conclusion}

The development of Javanese in the learning process from simple to complex has a greater impact in changing the ability to think and communicate with others. First, the Javanese language as the first language or the mother tongue of the Javanese society which has philosophical values, various advantages and virtues contained in it should always be developed. Second, the process of Unggah-Ungguh teaching and learning will improve the skills of learners in social interaction. It can affect the character development and communication competence of the learners. Third, the selection of appropriate media in Javanese language learning can form habits and patterned effects on the development of students in learning and support education in order to enhance the dignity of the nation through the values of the Javanese language.

\section{References}

[1] Sudaryanto, Tata Bahasa Baku Bahasa Jawa. Yogyakarta: Duta Wacana University Press, 1991.

[2] R. Lumban, T. Fbs, and U. Negeri, "TINGKAT TUTUR DALAM BUDAYA ' JAWA' DAN'BATAK ': Analisis Sosio-Pragmatik,” Diksi, 2007.

[3] S. S. W. C. Sasangka, Unggah-Ungguh Basa Jawa. Jakarta: Yayasan Paralingua, 2009.

[4] H. D. Brown, Principles of language learning and teaching. 2007.

[5] H. D. Brown, "Teaching by principles: an interactive approach to language pedagogy," Tesol Q., 2001.

[6] B. Kumaravadivelu, Understanding Language Teaching: From Method to Postmethod. 2006.

[7] M. A. K. Halliday and J. Webster, On language and linguistics. 2003.

[8] Supartinah, "Peran Pembelajaran Unggah-Ungguh Bahasa Jawa dalam Penanaman Nilai Sopan Santun di Sekolah Dasar," Didaktika, vol. 1, No 1, p. 56, 2006.

[9] G. S. Soepomo Poedjosoedarmo., Kunjana., Tingkat Tutur Bahasa Jawa. Jakarta: Pusat Pembinaan dan Pengembangan Bahasa, Departemen Pendidikan dan Kebudayaan, 1979.

[10] B. Purnomo, "Revitalisasi Unggah-Ungguh untuk Peningkatan Layanan Wisata di Jawa Tengah : Kajian Komunikasi Interpersonal Berbasis Kearifan Lokal Budi Purnomo,” vol. 2013, no. November, pp. 422-429, 2013.

[11] S. Haryana Harjawiyana, Kamus Unggah-Ungguh Basa Jawa. Yogyakarta: Kanisius, 2001.

[12] J. Richards, Communicative Language Teaching Today. 2006.

[13] E. M. Uhlenbeck, "The study of wordclasses in Javanese," Lingua, 1952.

[14] J. Turow, Media today: an introduction to mass communication. 2008.

[15] J. D. \& S. Heinich, Molenda M, Russel, Instructional Media And Technologies for Learning. New Jersey: Printice-Hall, Inc. A Simon \& Schuster Company, 1996.

[16] T. Vaughan, Multimedia : Making It Work. 2006.

[17] R. Shen, M. Wang, W. Gao, D. Novak, and L. Tang, "Mobile learning in a large blended computer science classroom: System function, pedagogies, and their impact on learning," IEEE Trans. Educ., 2009.

[18] R. M. Branch, Instructional Design: The ADDIE Aproach. 2009. 